\title{
Pengembangan Media Pembelajaran IPS Sejarah Berbasis Situs-Situs Tsunami Untuk Meningkatkan Kesadaran Sejarah Siswa SMP Negeri Kabupaten Pidie
}

\author{
Nina Suryana ${ }^{1}$, Heri Fajri' ${ }^{2}$, Sufandi Iswanto ${ }^{3}$ \\ 1, 2 Program Studi Pendidikan Sejarah, FKIP, Universitas Jabal Ghafur \\ ${ }^{3}$ Jurusan Pendidikan Sejarah, FKIP, Universitas Syiah Kuala
}

\begin{abstract}
Abstrak
Kurangnya pengintegrasian materi lokal pada mata pelajaran IPS, khususnya kajian sejarah ternyata berdampak terhadap rendahnya tingkat kesadaran sejarah siswa. Masalah tersebut menjadi alasan untuk mengembangkan media pembelajaran sejarah berbasis situssitus tsunami Aceh yang kaya nilai-nilai dan moral. Penelitian ini bertujuan untuk mengembangkan media pembelajaran IPS, khususnya bidang sejarah berbasis situs-situs tsunami untuk meningkatkan kesadaran sejarah siswa. Metode yang digunakan adalah penelitian pengembangan dari Borg and Gall, yang terapannya disederhanakan menjadi tiga tahapan yaitu pendahuluan, pengembangan dan uji keefektifan. Objek penelitian adalah siswa kelas VII SMP Negeri se-Kecamatan Sakti. Hasil penelitian menunjukkan bahwa selama ini umumnya guru masih kurang menggunakan media pembelajaran dan fasilitas sekolah masih minim. Guru jarang memasukkan materi yang berkaitan dengan peristiwa lokal, sehingga berdampak terhadap rendahnya kesadaran sejarah siswa. Temuan awal tersebut melandasi pengembangan media pembelajaran IPS sejarah berbasis situs-situs tsunami yang disesuaikan dengan KI dan KD, materi dan gambar. Pada uji keefektifan menunjukkan terdapat peningkatan nilai rata-rata kesadaran sejarah siswa secara signifikan. Terbukti dengan dengan peningkatan hasil perolehan skor post test kesadaran sejarah kelompok eksperimen.
\end{abstract}

Kata Kunci: Media, Situs, Tsunami, Sejarah

\section{Pendahuluan}

Kemajuan pendidikan tergantung kepada semua pihak yang terlibat, baik langsung dan tidak langsung. Modal yang utama yaitu semua pihak yang terlibat dalam bidang pendidikan harus mempunyai integritas. Terutama dalam rangka memperbaiki sistem, struktur dan proses pendidikan untuk menuju masa depan yang penuh perubahan. Seperti, sistem pendidikan nasional yang di citacitakan bangsa. Pengertian tersebut mengarahkan pada arti bila pendidikan sebagai sebuah proses dan hasil. Sebuah proses yang mana pendidikan secara penuh tanggung jawab untuk membimbing, memimpin dan mengarahkan peserta didik dengan berbagai masalah dalam pelaksanaannya. Sebagai hasil dapat dimaknai pendidikan merupakan wahana mengarahkan peserta didik mencapai guna perkembangan optimal sesuai dengan potensi diri yang di miliki, sehingga bisa menjadi manusia yang sadar dan bertanggungjawab sebagaimana tugas manusia (Aswasulasikin, 2018). Dalam arti luas pendidikan menekankan pada tindakan atau pengalaman yang memiliki pengaruh dan berhubungan dengan pertumbuhan dan perkembangan mind, character dan physical ability. Dalam arti teknis, pendidikan juga merupakan pendidikan karakter masyarakat yang 
dilakukan melalui lembaga pendidikan dan mentransformasikan warisan pengetahuan, nilai dan keterampilan dari generasi ke generasi (George F.K dalam Siswoyo, 2014). Namun realitanya yang terjadi bahwa kualitas manusia Indonesia sebagai sumber daya yang potensial masih jauh dari harapan. Realitas tersebut karena masih rendahnya kualitas pendidikan di Indonesia (Widodo, 2015).

Masalah yang terjadi dalam kehidupan masyarakat seperti ketimpangan moral, akhlak, masalah sosial, ekonomi, politik dan jati diri bangsa menjadi tanda dan, bukti bahwa penyelenggaraan pendidikan kita masih sangat memperihatinkan (Rokhman \& dkk, 2006). Menanggapi masalah ketimpangan yang terjadi dalam kehidupan masyarakat, erat kaitannya dengan penerapan pembelajaran Ilmu Pengetahuan Sosial di sekolah.

Oleh karena masalah-masalah tersebut belum sesuai dengan maksud dan tujuan pembelajaran IPS di sekolah selama ini. Menurut Surahman \& Mukminan, (2017) kehadiran pelajaran IPS seyogyanya menjadi jawaban dan solusi untuk menghadapi permasalahan bangsa. Karena pembelajaran IPS dapat menjadi penguatan peserta didik dalam menghadapi masalah sosial. Sebab di dalamnya diajarkan berbagai masalah sosial dan kehidupan manusia. Maka dengan itu output dari pembelajaran IPS akan menghasilkan manusia yang mampu mengambil keputusan, mencari solusi dan menyelesaikan masalah. Ahmadi, dkk (2011) lebih lanjut menjelaskan bahwa pelajaran IPS dapat membimbing peserta didik menghadapi kenyataan dalam lingkungan sosial dan, dapat menghadapi masalah sosial yang terjadi dengan lebih arif dan bijaksana.

Dalam pembelajaran IPS, peserta didik harus bisa mengembangkan pengetahuan dan mendapatkan pembelajaran yang menyenangkan, bermakna dan bermutu. Selain itu, dapat membekali peserta didik berguna untuk masa depannya, keterampilan sosial dan intelektual dalam membina perhatian. Selain kepedulian sosial sebagai SDM yang bertanggung jawab dalam merealisasikan tujuan pendidikan nasional.

Salah satu bekal yang harus dimiliki peserta didik adalah adanya sikap tanggung jawab. Berkaitan dengan itu, seyogyanya melalui pembelajaran IPS yang dirumuskan berdasarkan fakta dan fenomena yang ada di lingkungan peserta didik. Kiranya dari proses tersebut akan menumbuhkan rasa tanggung jawab. Salah satu tanggung jawab yang harus di miliki peserta didik adalah kesadaran terhadap sejarah. Kesadaran sejarah erat hubungannya dengan masalah moral peserta didik. Oleh karena itu, tanggung 
jawab memiliki hubungan dengan moral. Sebab manusia yang bermoral adalah manusia yang memiliki kesadaran. Jika kesadaran tersebut kurang ditanamkan, maka berdampak pada kemerosotan moral peserta didik. Apalagi di era saat ini tantangan terbesar bangsa tatkala menghadapi imperialisme cultural. Tantangan yang banyak membawa kemudaratan sehingga yang lokal sentris kian terabaikan.

Kesadaran sejarah merupakan bentuk kejiwaan yang mana kebudayaan membuat pertanggungjawaban masa silam. Kesadaran sejarah juga mengandung pengertian sebagai hasil pemikiran dan kenyataan seorang terhadap peristiwa masa lalu yang ditimbulkan oleh aktivitas manusia, yang mempergunakan pengertian untuk kepentingan masa sekarang (Sartono Kartodirdjo dalam Suryana, 2014).

Dengan kesadaran sejarah pula manusia mampu merefleksikan secara kontinyu tentang kompleksitas perubahan dan, mampu menghargai kerumitan upaya pengungkapan terhadap kejadian yang melingkupinya, serta menghargai keunikan dari masingmasing keadaan dan fenomena masa lampau (Soedjatmoko Tim Pengembang Ilmu Pendidikan FIP UPI, 2007). Berpijak pada taksonomi Bloom, dari aspek kognitif dan afektif kesadaran sejarah berkaitan dengan berpikir dan bertindak sesuai dengan perkembangan zaman. Menumbuhkan sikap menghargai berbagai aspek kehidupan masa kini yang merupakan hasil dari masa lampau (Hamid, 2014). Dengan demikian, kesadaran tersebut berguna untuk menanamkan dan mengembangkan sikap bertanggung jawab, bermoral dan arif dalam memelihara keseimbangan kelestarian lingkungan mereka.

Salah satu cara menamamkan kembali kesadaran sejarah tersebut ialah dengan mengintegrasikan materi masa lampau yang ada pada lingkungan peserta didik. Sebagaimana Trianto (2011) menjelaskan bahwa pembelajaran lebih bermakna, dengan konsep atau informasi baru harus dikaitkan dengan konsep yang ada dalam struktur kognitif dan afektif peserta didik. Guru sebagai fasilitator merupakan elemen penting dalam penanaman kesadaran sejarah.

Guru profesional diharapkan mampu membuat berbagai terobosan untuk membantu peserta didik. Gunanya guna memperoleh berbagai pengetahuan lokal dari peninggalan masa lampau. Sehingga dari materi tersebut peserta didik memiliki tanggung jawab terhadap peninggalan dan meningkatnya kesadaran sejarah. Untuk itu perlu formulasi perantara yang tepat terutama perihal pemanfaatan media. Media pembelajaran salah satu alat yang bisa dijadikan guru sebagai perantara untuk 
menyampaikan materi peninggalan masa lampau. Selain sebagai alat bantu, media yang menarik juga memudahkan guru dalam menyampaikan materi. Sebagaimana pernyataan Agung dan Wahyuni (Agung \& Wahyuni, 2013), media dapat memberikan kemudahan belajar siswa dan guru, tema lebih abstrak dapat diwujudkan secara konkret, proses pelajaran tidak membosankan dan tidak monoton serta dapat menarik minat peserta didik.

Wati (2016) menjelaskan media pembelajaran juga dapat memberikan kesamaan pengalaman dan pemahaman peserta didik tentang peristiwa yang pernah terjadi di lingkungan mereka. Selain itu, dengan media pembelajaran peserta didik akan dimungkinkan untuk berinteraksi langsung dengan guru, masyarakat dan lingkungannya. Termasuk beberapa lingkungan sekitar sebenarnya bisa dimanfaatkan sebagai media belajar. Kondisi lingkungan yang membangkitkan peserta didik untuk dapat kreatif, aktif dan inspiratif sehingga pembelajaran dapat bermanfaat (Brigida Intan Printina, 2017)

Salah satu wilayah yang memiliki banyak peninggalan dari peristiwa masa lampau adalah Aceh. Peninggalan di Aceh seperti peristiwa tsunami yang terjadi pada tahun 2004 silam. Gempa bumi dan gelombang tsunami telah menyebabkan terbentuknya situs-situs tsunami. Situs- situs tersebut hampir bisa ditemui sepanjang garis pantai Aceh. Situs-situs tersebut ada yang terjadi secara alami atau yang terbawa gelombang tsunami. Namun ada juga situs yang merupakan buatan manusia, seperti monumen. Situssitus tersebut memiliki fungsi untuk dapat mengembalikan ingatan manusia terhadap musibah dan tetap menjaga situs-situs masa lampau tersebut. Pada lingkup yang lebih luas selama ini peserta didik selalu diajarkan mempelajari lingkup nasional.

Padahal peserta didik juga harus diajarkan mempelajari apa yang ada di daerahnya yang sudah pasti menjadi identitasnya secara lokalitas. Mereka perlu mengetahui latar belakang masa lampu yang ada disekitarnya. Senada dengan Hamid (2014) mengemukakan di sejumlah daerah di tanah air, selalu ditemukan objek-objek sejarah, diantaranya monumen yang mengingatkan pada kejadian masa silam. Dengan mempelajari objek sejarah tersebut memunculkan tumbuhnya kesadaran sejarah generasi muda.

Berdasarkan hasil observasi yang dilakukan peneliti pada SMP Negeri SeKecamatan Sakti Kabupaten Pidie, selama ini guru masih kurang mengetahui tentang materi lokal yang bisa diintegrasikan pada materi buku paket yang digunakan. Selain itu, kurangnya pemahaman guru terhadap media 
pembelajaran beserta jenisnya yang menjadikan guru, secara umum hanya fokus pada materi buku paket saja. Hal ini berdampak negatif pada minat peserta didik untuk belajar IPS terutama sejarah. Perlu adanya solusi bagi guru dan peserta didik supaya pembelajaran IPS menjadi lebih menyenangkan. Terutama terkait materi lokal berupa situs-situs tsunami yang selama ini masih kurang diketahui peserta didik dan guru.

Oleh sebab tingkat kesadaran sejarah peserta didik masih kurang terhadap situs-situs yang memiliki nilainilai dan moral. Permasalahan tersebut memberikan gambaran bahwa perlu adanya formulasi inovasi untuk meningkatkan kesadaran sejarah siswa SMP Negeri se-Kecamatan Sakti. Formulasi yang dimaksud adalah media pembelajaran IPS sejarah yang bertujuan untuk meningkatkan kesadaran sejarah.

Tujuan penelitian ini adalah Pertama, mengeksplorasi bagaimana penggunaan media pembelajaran IPS dan kesadaran sejarah siswa SMP Negeri seKecamatan Sakti, Kedua, mengembangkan media pembelajaran IPS dengan basis situs tsunami Aceh, dan Ketiga, merumuskan efektifitas media pembelajaran IPS berbasis situs tsunami untuk meningkatkan kesadaran sejarah siswa SMP Negeri se-Kecamatan Sakti.

\section{Tinjauan Pustaka}

\section{A. Media Pembelajaran Audio Visual}

Secara harfiah media berasal dari bahasa Latin yaitu Medius. Kata medius memiliki arti tengah, perantara atau pengantar. Dalam pembelajaran media sering diartikan sebagai alat grafis, photografis, atau alat elektronik yang berfungsi untuk menangkap, memproses dan menyusun kembali informasi visual dan verbal (Wati, 2016). Berdasarkan fungsinya media pembelajaran menjadi alat bantu yang dapat menjelaskan sebagian atau keseluruhan program pembelajaran yang sulit dijelaskan secara verbal.

Sedangkan dari cirinya, media dapat dilihat dari kemampuannya sendiri dalam membangkitkan rangsangan indera penglihatan, pendengaran, perabaan dan penciuman (Musfiqon, 2012). Dalam pembelajaran terdapat banyak jenis media, yaitu media audio visual. Menurut Rohani (Ahmadi \& Ibda, 2018) media audio visual merupakan media instruksional modern yang sesuai dengan perkembangan zaman atau kemajuan ilmu pengetahuan dan teknologi. Media ini meliputi yang dapat dilihat dan dapat didengar.

Tampilan media audio visual menurut Wati (2016) berupa unsur gambar dan suara secara bersamaan saat mengkomunikasikan pesan atau informasi yang disampaikan. Media ini juga mengungkap objek dan peristiwa sebagaimana keadaan yang sesungguhnya. 
Media audio visual secara khusus memiliki fungsi. Sebagaimana menurut Miarso (2004) mampu merangsang otak hingga bisa berfungsi secara optimal, mengatasi segala keterbatasan pengalaman, menjadikan adanya interaksi langsung antara guru dengan siswa, menghasilkan keseragaman pengamatan, membangkitkan keinginan minat baru, memberikan pengalaman yang kongkrit dan meningkatkan kemampuan ekspresi dari guru maupun siswa.

Berdasarkan beberapa definisi tersebut disimpulkan bahwa media pembelajaran khususnya media audio visual merupakan alat yang dibutuhkan dalam pendidikan. Penggabungan antara audio yang berarti pendengaran dan visual berarti penglihatan dapat membangkitkan rangsangan indera pendengaran dan penglihatan siswa. Tampilan media audio visual yang menarik dapat menjadi perangsang otak siswa. Media audio visual juga dapat merangsang keinginan belajar dan minat belajar serta, meningkatkan ekspresi siswa dan guru.

\section{B. Ilmu Pengetahuan Sosial (IPS)}

Ilmu Pengetahuan Sosial (IPS) merupakan istilah yang muncul dari penyederhanaan disiplin ilmu-ilmu sosial dan humaniora. Secara umum IPS memiliki dua definisi, yaitu IPS sebagai mata pelajaran dan IPS sebuah kajian akademik. Namun, dalam kajian berikut difokuskan pada IPS sebagai mata pelajaran yang terdapat pada kurikulum khususnya jenjang Sekolah Menengah Pertama (SMP). Mata pelajaran IPS merupakan program pendidikan di tingkat sekolah dan LPTK, serta bukan sub disiplin ilmu tersendiri, sehingga tidak akan ditemukan baik dalam nomenklatur filsafat ilmu, disiplin ilmuilmu sosial maupun ilmu pendidikan (Somantri, 2001). Pada jenjang Sekolah Menengah Pertama, mata pelajaran IPS disebut juga sebagai mata pelajaran terpadu yang terdapat empat cabang ilmu pengetahuan, antara lain sejarah, geografi, ekonomi, dan sosiologi.

Mata pelajaran IPS disebut pula sebagai mata pelajaran yang menelaah tentang manusia dalam hubungan bermasyarakat. Karena manusia sebagai makhluk sosial mengadakan hubungan sosial dengan sesamanya, mulai dari keluarga sampai masyarakat global (Joebagio dan Sariyatun, 2015). Maka dari itu, mata pelajaran IPS hadir dengan memiliki konsep untuk membantu siswa membangun landasan untuk memahami sebuah kenyataan yang bertitik tolak dari perspektif tentang kenyataan hidup (Brank dalam Wiriaatmadja, 2002).

Hal tersebut sesuai dengan tujuan mata pelajaran IPS, yaitu untuk membantu tumbuh berfikir keilmuan sosial dan memahami konsepnya, serta membantu tumbuhnya warga negara yang baik. Pembelajaran IPS bisa bervariasi mulai dari penekanan pendidikan kewarganegaraan, 
pemahaman dan penguasaan konsep ilmuilmu sosial, bahkan masalah dalam masyarakat (Somantri, 2001). Berdasarkan beberapa definisi tersebut dapat disimpulkan bahwa mata pelajaran IPS merupakan salah satu mata pelajaran yang ada pada jenjang SMP. Pada saat ini IPS sendiri merupakan mata pelajaran terpadu yang dikemas beberapa cabang ilmu pengetahuan, seperti sejarah, geografi, ekonomi, dan sosiologi. Mata pelajaran IPS bertujuan untuk membentuk ingatan peserta didik berdasarkan fakta yang terjadi. Selain itu, peserta didik sadar akan tanggung jawabnya terutama terhadap lingkungan sekitarnya.

\section{Situs-situs Tsunami Aceh}

Secara umum situs dapat diartikan sebagai objek dan tempat dari sebuah peristiwa. Objek tersebut tidak selalu dibuat atau dibangun manusia. Artinya, ada situs yang terbentuk karena bencana alam bukan buatan manusia. Menurut Irwansyah (2012) tsunami berasal dari bahasa Jepang yaitu tsu yang berarti pelabuhan dan nami yang berarti ombak. Tsunami bisa diartikan sebagai gelombang besar yang menyapu daratan. Penyebabnya bisa mulai dari gempa karena penggeseran lempeng bumi atau, gempa yang disebabkan gunung berapi di bawah laut.

Menurut Bryant (2007) tsunami juga bisa disebabkan oleh meletusnya gunung merapi, tanah longsor bawah laut, tubrukan meteorit dengan samudra atau kasus fenomena meteorologi. Orang Aceh memiliki istilah tersendiri mengenai tsunami. Jika dalam bahasa Jepang gelombang besar tersebut dikenal dengan tsunami, maka dalam istilah orang Aceh dikenal dengan ie-beuna dan dalam istilah bahasa Simeule dikenal dengan seumong. Dalam beberapa catatan sejarah Aceh, tsunami bukan saja terjadi pada tahun 2004 silam, namun sebelumnya juga sudah pernah terjadi. Menurut Muchsin \& Umar (2017) tsunami sudah terjadi tiga kali, yaitu tahun 1797, 1833 dan 2004.

Tsunami yang terjadi pada tahun 2004 ternyata paling banyak memberikan perubahan yang signifikan. Perubahan tersebut bisa dilihat dari kehidupan masyarakat dan realitas alam serta geologisnya. Bukan saja membawa perubahan terhadap kehidupan masyarakat dan geologisnya, gelombang tsunami yang terjadi di Aceh juga telah memporak-porandakan beberapa daerah, terutama daerah pesisir Aceh. Dahsyatnya gelombang tsunami ternyata berdampak terhadap keberadaan situs-situs di daerah pesisir Aceh.

Menurut Suryana (2014) tsunami Aceh telah menyebabkan terbentuknya situs-situs tsunami. Banyak situs-situs tsunami di Aceh muncul secara alami tanpa campur tangan manusia. Diantaranya akibat dari gulungan ombak, adapula situssitus yang secara khusus dibangun untuk mengenang peristiwa tersebut, yaitu 
meseum tsunami. Situs-situs tersebut menjadi bukti dari sebuah peristiwa besar dan memiliki nilai. Oleh karena itu, sudah sepatutnya menjaga situs-situs tersebut.

\section{Kesadaran Sejarah}

Secara bahasa kata kesadaran berasal dari kata sadar yang mendapatkan imbuhan ke-an yang berarti merasa, yakin, insyaf, mengerti atau tahu dan bangun dari tidur. Kesadaran berarti keinsyafan, keadaan mengerti akan harga dirinya yang timbul karena diperlakukan secara adil, hal yang dirasakan atau dialami oleh seseorang (Departemen Pendidikan dan Kebudayaan, 1993). Jadi, kesadaran adalah hati dan pikiran yang telah terbuka tentang apa yang telah dikerjakan.

Namun, kesadaran mencakup persepsi dan pemikiran yang secara samarsamar disadari individu sehingga, pada akhirnya perhatiannya terpusat (Sujarwa, 2011). Kata sejarah secara umum diartikan sebagai kesusasteraan lama, silsilah, asal, usul dan peristiwa yang benar-benar terjadi di masa lampau (Ali, 2005). Sederhananya sejarah berarti peristiwa yang dapat ditimbulkan oleh aktivitas manusia di masa lalu di suatu tempat tertentu (Widja, 1989).

Sejarah juga mengkaji tempat di mana peristiwa pernah terjadi. Dalam arti yang benar-benar terjadi di lokasi tertentu. Penggabungan kata kesadaran dengan sejarah memberikan pengertian yang berbeda lagi. Menurut Widja (1989) kesadaran sejarah merupakan refleksi sikap yang bersumber pada kondisi kejiwaan yang menunjukan tingkat penghayatan makna serta hakikat sejarah. Kesadaran sejarah sangat berarti dan diperlukan. Menurut Ch Anshoriy (2010) kesadaran sejarah sangat berarti dalam menghadapi yang dilihat saat ini, khususnya pada generasi muda yang cenderung frustasi. Kesadaran sejarah diperlukan untuk melihat realitas sosial yang sekarang dengan berbagai macam masalah. Kesadaran sejarah bisa menjadi cara supaya mampu melihat masalah, termasuk masalah moral.

Kesalahan yang diperbuat manusia bisa diatasi dengan mengetahui kesadaran sejarah. Seperti yang kemukakan Tamburaka (1999) dari perbuatan tersebut, dapat bercermin dan menilai perbuatan mana yang merupakan keberhasilan dan kegagalan, dengan demikian dapat lebih berhati-hati agar kegagalan tidak terulang kembali. Dengan demikian, kesadaran sejarah pada manusia penting bagi pembinaan budaya bangsa. Dalam konteks ini bukan hanya sekedar memperluas pengetahuan, melainkan harus diarahkan ke kesadaran penghayatan nilai-nilai dan peristiwa yang relevan yang pernah terjadi di lingkungannya.

\section{Metode Penelitian}

Penelitian ini merupakan pengembangan media pembelajaran IPS 
berbasis situs tsunami untuk meningkatkan kesadaran sejarah siswa SMP Negeri di Kecamatan Sakti. Prosedur yang digunakan mengacu pada penelitian dan pengembangan. Prosedur penelitian dan pengembangan memiliki dua tujuan, yaitu mengembangkan produk dan menguji keefektifan produk yang dikembangkan untuk mengukur tingkat keefektifannya (Gall \& Borg, 2003). Penelitian ini biasanya dilakukan sistematis dan bertujuan mencaritemukan, merumuskan, memperbaiki, mengembangkan, menghasilkan dan menguji keefektifan produk (Iswanto, dkk, 2015).

Adapun prosedur pengembangan ini mengambil model Borg and Gall terdiri sepuluh langkah, antara lain: a). Assess needs to identity goal, b). Conduct instructional analyze, c). Analyze learners and contexts, d). Write performance objectives, e). Develop assesment instruments, f). Develop instructional, g). Develop and select instructional materials, h). Design and conduct formative evaluation of instruction, i). Revise instructional dan j). Design and conduct summative evaluation (Iswanto, dkk, 2015).

Namun langkah tersebut dapat disederhanakan, Pertama, dimulai dari rumusan masalah atau tujuan penelitian dengan jelas, Kedua, lakukan studi pendahuluan yang sistematis, Ketiga, menyusun rancangan penelitian pengembangan, Keempat, melaksanakan penelitian pengembangan sesuai dengan rancangan yang ditetapkan, Kelima, melakukan evaluasi proses dan produk, analisis data dan refleksi serta Keenam, menyusun laporan hasil penelitian (Yusuf, 2017). Pada langkah evaluasi, melibatkan ahli dengan beragam latar belakang. Karena situasi dan tahapan tersebut penelitian ini disebut sebagai pekerjaan yang bersifat multi (Putra, 2013). Sepuluh langkah itu selanjutnya disederhanakan menjadi dua tahapan.

Tahapan tersebut, yaitu a). tahap pendahuluan, bertujuan mengetahui media pembelajaran yang digunakan guru selama ini, mengetahui pemahaman guru dan siswa terkait kesadaran sejarah dan analisis kebutuhan guru dan siswa terhadap media yang dikembangkan, b). tahap pengembangan, bertujuan menguji keefektifan media pembelajaran IPS. Tahap ini dilakukan pre test dan post test di dua kelompok yang diberikan media yang berbeda. Pada kelompok kontrol diberikan media berbasis power point, sedangkan kelompok eksperimen diberikan media audio visual.

\section{Hasil Dan Pembahasan}

\section{A. Tahap Pendahuluan}

\section{Penggunaan Media Pembelajaran IPS} SMP Negeri Se-Kecamatan Sakti

\section{Selama Ini}

Berdasarkan hasil observasi dan wawancara dengan guru IPS yang 
dilakukan selama dua bulan di SMP Negeri Kecamatan Sakti, yaitu SMP Negeri 1 Sakti, SMP Negeri 3 Sakti dan SMP Negeri 4 Sakti. Diperoleh gambaran umum, Pertama, dalam proses pembelajaran di kelas yang sudah berlangsung selama ini, secara umum guru telah menggunakan metode cooperative learning. Namun guru mengakui bahwa selama ini lebih sering menggunakan metode konvensional. Hal ini disebabkan karena minimnya pemahaman guru terhadap jumlah atau macam-macam metode yang bisa digunakan dalam pembelajaran IPS.

Maka tidak heran jika saat proses pembelajaran IPS berlangsung, siswa kurang antusias dan terlihat bosan. Kedua, terkait dengan media pembelajaran yang digunakan selama ini di ketiga sekolah. Hasilnya menunjukkan masing-masing sekolah tidak jauh berbeda. Secara umum penggunaan media pembelajaran masih jarang. SMP Negeri 1 Sakti dan SMP Negeri 2 Sakti terdapat fakta guru masih jarang menggunakan media pembelajaran.

Selama ini untuk menunjang proses pembelajaran guru kadang hanya menggunakan microsof office Powerpoint. Di SMP Negeri 4 Sakti diperoleh fakta yang berbeda. Selama ini guru sudah menggunakan media pembelajaran seperti microsof office Powerpoint, film dokumenter yang bersumber dari youtube, media gambar, peta konsep dan peta. Penggunaan media pembelajaran memang berkaitan erat dengan fasilitas sekolah. Dilihat dari fasilitas ketiga sekolah bisa dikatakan belum cukup memadai untuk mendukung penggunaan media pembelajaran. Masing-masing sekolah hanya memiliki satu unit LCD dan Infokus. Karena keterbatasan tersebut, selama ini guru harus bergantian dengan guru mata pelajaran lain. Selain itu, sekolah juga belum memiliki ruangan khusus, seperti laboratorium komputer dan jaringan internet.

Ketiga, latar belakang guru sangat mempengaruhi bagaimana penguasaan materi pembelajaran dan media pembelajaran. Hasil wawancara menunjukkan ternyata ketiga sekolah tidak ada guru yang berlatar belakang pendidikan IPS. Pada dua sekolah guru berlatar belakang dari Sarjana Pendidikan Ekonomi dan satu sekolah berlatar belakang Sarjana Pendidikan Sejarah.

\section{Tingkat Kesadaran Sejarah Siswa} Terhadap Situs-Situs Sejarah

Pembelajaran dengan lingkungan merupakan satu konsep pembelajaran yang mengidentikkan lingkungan menjadi sumber belajar. Oleh karenanya, lingkungan bisa dimanfaatkan sebagai sumber inspirasi dan motivator dalam meningkatkan peserta didik (Uno \& Mohammad, 2013). Namun selama ini tingkat kesadaran sejarah peserta didik masih kurang. Terdapat sejumlah masalah yang dihadapi untuk meningkatkan 
kesadaran sejarah. Selama ini guru hanya menekankan pada aspek karakter yang terdapat pada buku Kurikulum 2013, tanpa mengajarkan karakter lainnya. Padahal dengan belajar lingkungan sekitar bisa menumbuhkan nilai karakter atau sikap lain. Misalnya, pembelajaran berbasis materi lingkungan. Berdasarkan hasil wawancara dengan siswa ditemukan keterangan bahwa peserta didik masih minim pengetahuan tentang sejarah lokal, terutama situs-situs peninggalannya.

Padahal banyak peninggalanpeninggalan bersejarah yang bisa dijadikan sebagai sumber dan materi pembelajaran. Ditambah lagi dengan cara mengajar guru yang masih monoton pada materi yang diajarkan, yaitu terfokus pada buku paket Kurikulum 2013 saja. Padahal pengembangan materi berbasis sejarah lokal begitu penting untuk meningkatkan kesadaran sejarah peserta didik.

\section{Kebutuhan Guru dan Siswa terhadap}

\section{Media IPS Berbasis Situs-Situs}

\section{Tsunami}

Berangkat dari kondisi penggunaan media pembelajaran IPS yang selama ini digunakan di SMP Negeri Se-Kecamatan Sakti, perencanaan pengembangan media untuk guru dan siswa menjadi penting untuk dikembangkan. Berdasarkan hasil pengamatan dan wawancara pada tahap sebelumnya, telah membantu peneliti menyusun prototype pengembangan media. Menilik dari aspek lingkungan, banyak peristiwa yang meninggalkan bukti dan dapat dikembangkan menjadi materi pembelajaran. Pengembangan tersebut bisa melalui situs bersejarah. Situs yang merupakan bukti dari kejadian yang mengandung nilai yang sering terabaikan. Sebagaimana dari temuan sebelumnya, menunjukkan bahwa siswa di SMP Negeri Se-Kecamatan Sakti masih kurang mengetahui situs-situs bersejarah di Aceh. Padahal Aceh salah satu provinsi yang dianggap memiliki banyak situs bersejarah.

Situs tersebut bervariasi, mulai situs mozaik masa prasejarah, masa HinduBudha, masa Islam, masa kolonial Belanda, dan lebih menariknya situs-situs Tsunami Aceh tahun 2004. Situs tsunami Aceh salah satu contoh sebuah peristiwa 15 tahun silam yang banyak meninggalkan sejarah. Sepanjang garis pantai Aceh, sekarang banyak situs yang masih bisa dilihat sebagai bukti kekuasaan-NYA. Peninggalan tersebut setidaknya dapat meningkatkan kesadaran sejarah peserta didik dalam peristiwa masa lampau.

\section{B. Pengembangan Media Pembelajaran IPS Berbasis Situs-Situs Tsunami}

Berdasarkan hasil observasi dan wawancara yang telah dilakukan peneliti pada SMP Negeri Se-Kecamatan Sakti. Maka dilakukan pengembangan media pembelajaran menggunakan prosedur dari Borg and Gall. Penyusunan masih berupa prototype yang menitikberatkan pada materi berbasis situs-situs tsunami. Hal 
tersebut bertujuan untuk mengukur tingkat kesadaran sejarah siswa. Materi yang dikembangkan telah disesuaikan dengan Kompetensi Inti (KI) dan Kompetensi Dasar (KD). Penentuan KI dan KD telah disesuikan dengan kebutuhan berdasarkan keadaan lingkungan siswa, yaitu kajadian yang bersifat faktual. Prototype yang dikembangkan juga disesuaikan dengan langkah-langkah pembelajaran dalam kelas. Mulai dari kesesuaian durasi media dengan jam yang disediakan, materi, gambar yang jelas dan mengevaluasi media. Tabel 1 menunjukkan model prototype media yang telah disusun.

Tabel 1. Prototype Media Pembelajaran IPS Sejarah Berbasis Situs-Situs Tsunami

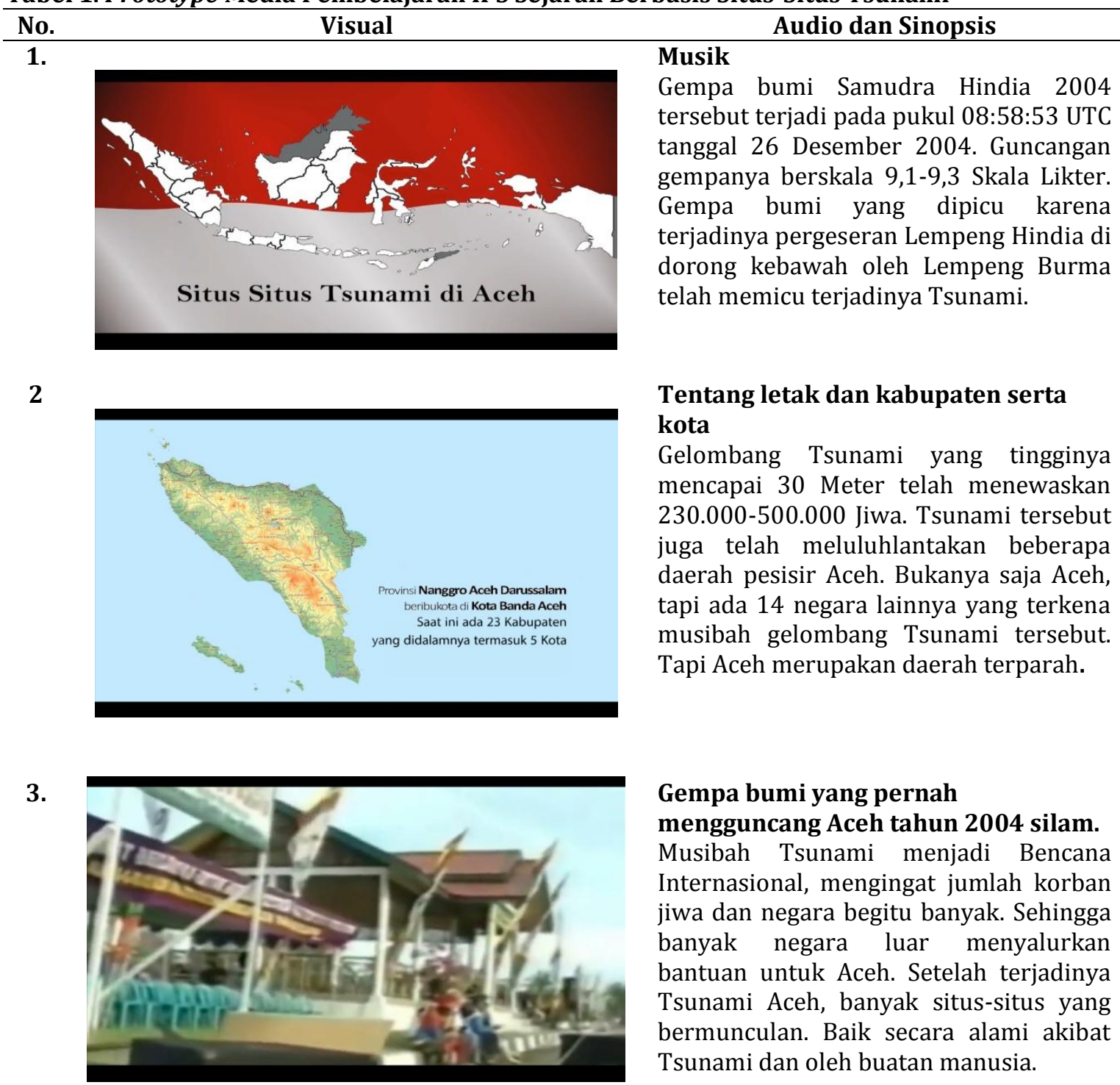

4. 


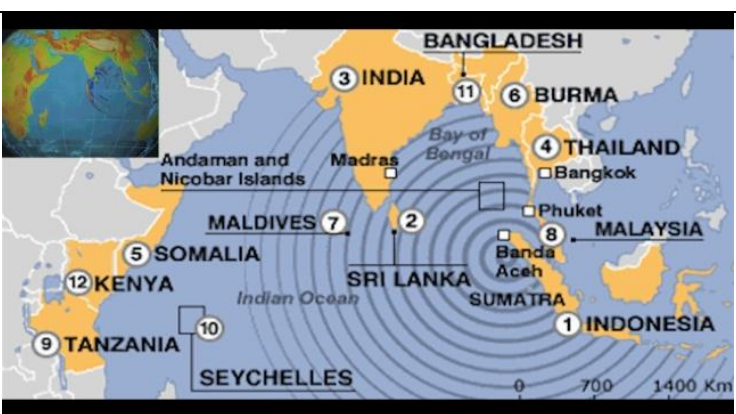

\section{Korban Tsunami \\ Tsunami yang banyak menelan korban jiwa. Bukan saja Aceh, tapi ada 14 negara lainnya yang terkena musibah gelombang tsunami.}

5.

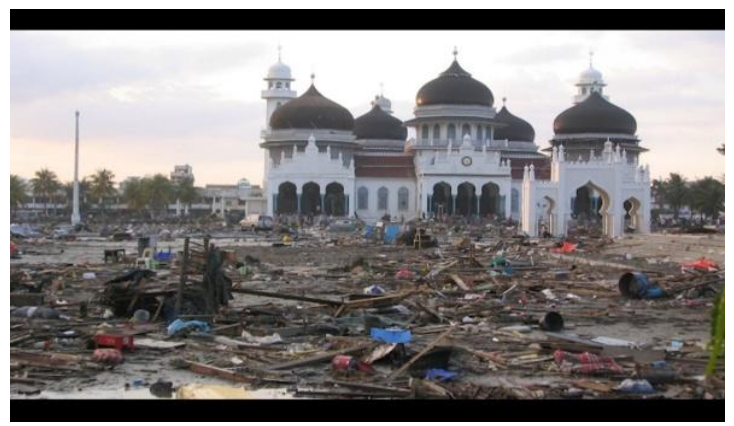

6.

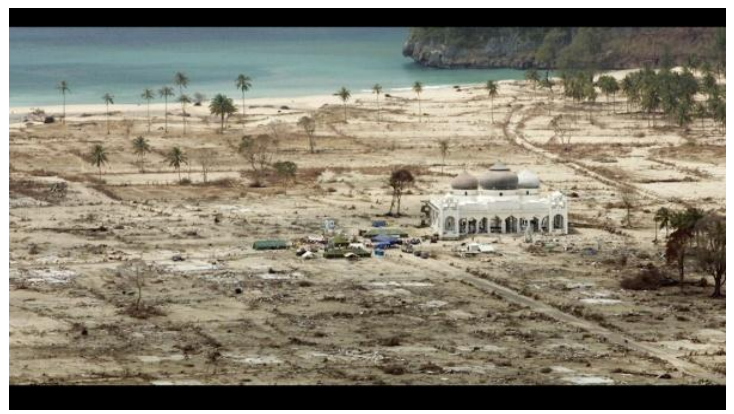

\section{Musibah Tsunami}

Musibah tsunami menjadi musibah internasional.

\section{Pasca Tsunami}

Pasca musibah gelombang tsunami, di Aceh banyak muncul situs-situs tsunami yang dijadikan untuk mengenang peristiwa tsunami

7.

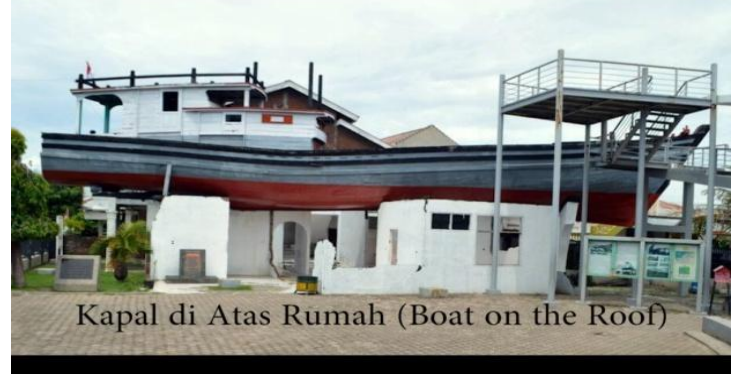

8.

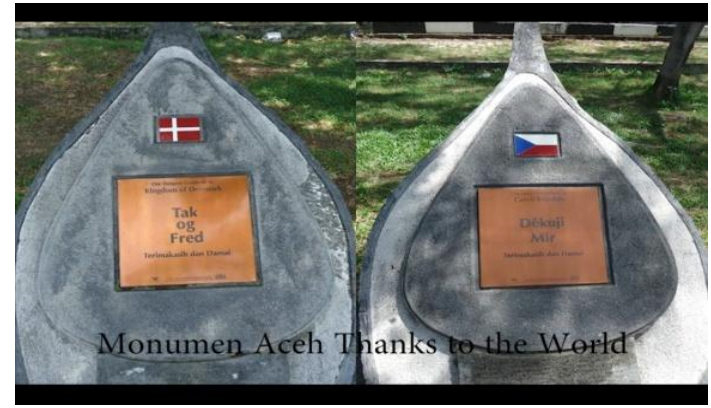

\section{Situs Kapal di Atas Rumah}

Salah satu situs alami yang terjadi akibat Tsunami langsung, situs ini terletak di Lampulo, Kota Banda Aceh. Diberi nama Kapal di Atas Rumah karena sebuah feri yang berlabuh diatas rumah. Saat kejadian kapal feri tersebut menyelamatkan 59 orang.

\section{Situs Monumen Aceh "Thanks to the World"}

Situs ini terletak di Blang Padang Kota Banda Aceh. Monumen ini berbentuk cetakan batu cetakan dengan bertuliskan kata Terima Kasih dan Damai, dari berbagai bahasa dari banyak negara yang diterjemahkan dalam bahasa Indonesia. Negara tersebut sekaligus negara-negara yang pernah membantu Aceh. 
9.

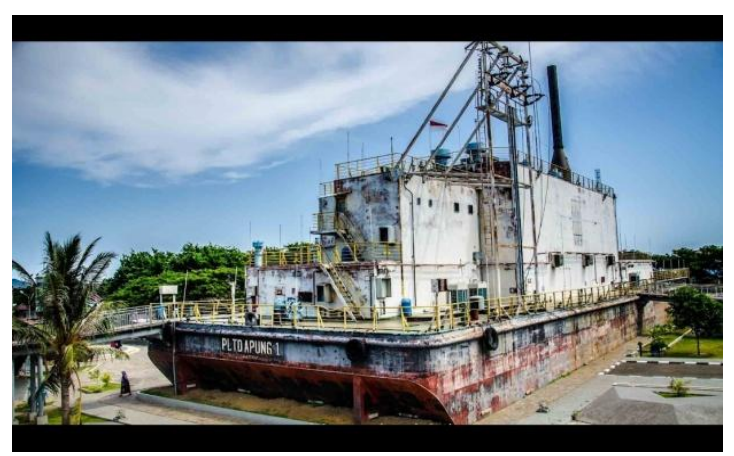

10.

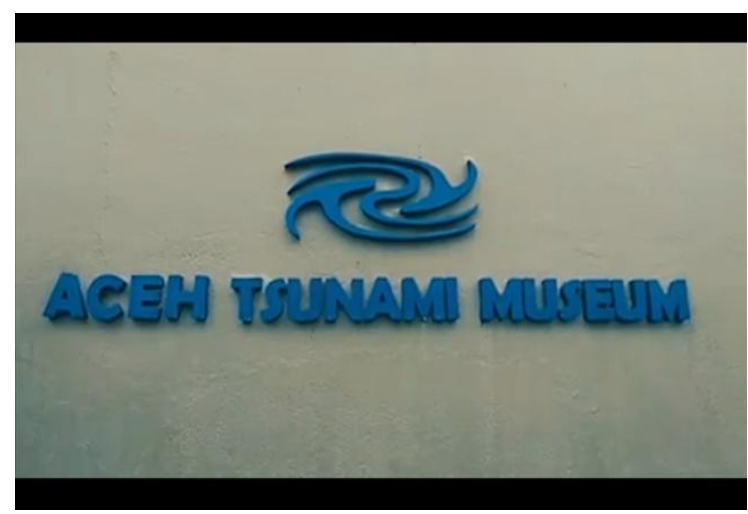

11.

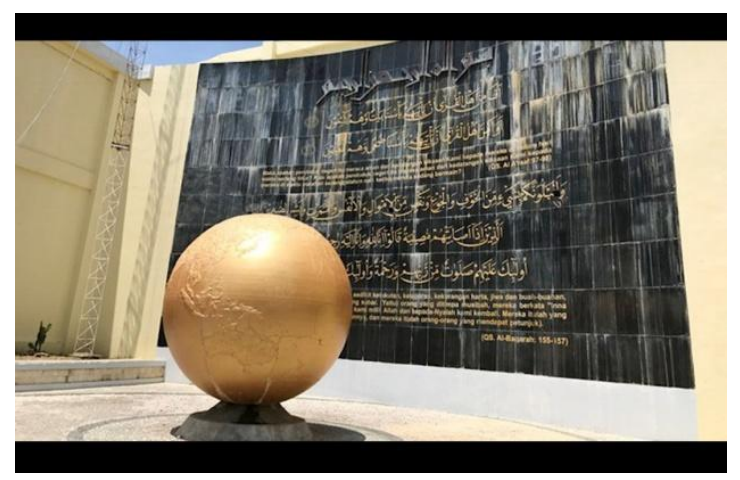

12.

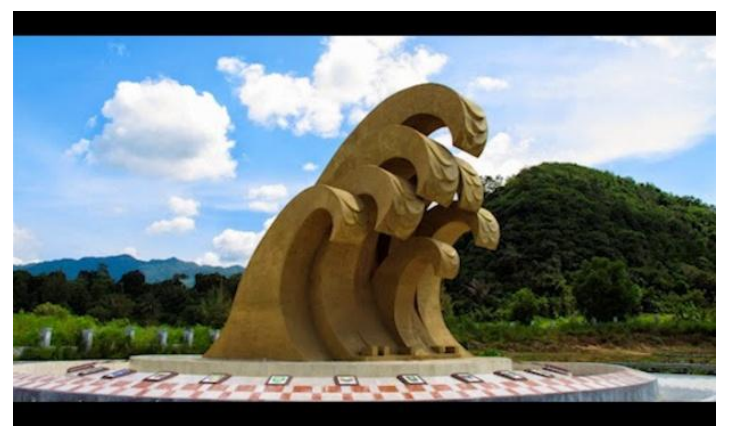

\section{Situs PLTD Apung}

Kapal PLTD Apung merupakan situs alami yang terjadi akibat Tsunami. Situs ini terletak di Desa Punge Blang Cut, Kota Banda Aceh. Kapal ini merupakan kapal pembangkit tenaga listrik yang berukuran besar, saat Tsunami kapal tersebut terseret ke daratan sekitar meter dari laut. Konon, dibawah kapal tersebut masih banyak mayat korban tsunami yang masih belum bisa diambil.

\section{Situs Museum Tsunami}

Museum Tsunami menjadi ikon Kota Banda Aceh pada saat ini. Namanya diberi Museum Tsunami karena museum yang dirancang Ridwan Kamil bertujuan untuk tempat peninggalan tsunami. Sehingga tidak heran jika Museum yang terletak di pusat Kota Banda Aceh. Hal ini memiliki bentuk seperti gelombang dan di dalamnya juga terdapat beberapa peninggalan Tsunami dan nama-nama korban tsunami.

\section{Situs Monumen Tsunami Sigli}

Monumen Tsunami Sigli yang terletak di Desa Kuala Pidie, Kabupaten Pidie. Monumen tersebut di bangun untuk mengenang Tsunami di Sigli. Sehingga tidak heran jika monumen tersebut dibangun tepat di lokasi yang langsung terkena dampak tsunami, yang sekarang ini berlokasi di alun-alun kota Sigli. Monumen tersebut berbentuk Bola Dunia Raksasa dengan warna emas. Pada bola juga terdapat tulisan ayat suci Al-Qur'an. Bola tersebut juga dilengkapi dengan dinding yang bertuliskan nama-nama korban Tsunami.

\section{Situs Tugu Tsunami Lhoknga}

Situs ini terletak di Gampong Pasir Lhok Aron Kecamatan Lhoknga. Merupakan satu dari sekian banyak situs yang ada di Aceh Besar. Situs ini berupa tugu yang berbentuk gelombang Tsunami. Tugu tersebut memiliki tinggi sekitar 15 meter, bentuknya unik karena menyerupai gelombang yang bertingkat-tingkat. Tugu ini dibangun untuk mengenang bahwa di daerah tersebut pernah terjadi musibah maha dahsyat. Namun sayang tugu tersebut saat ini kondisinya sangat memprihatinkan karena tidak terawat. 
13.

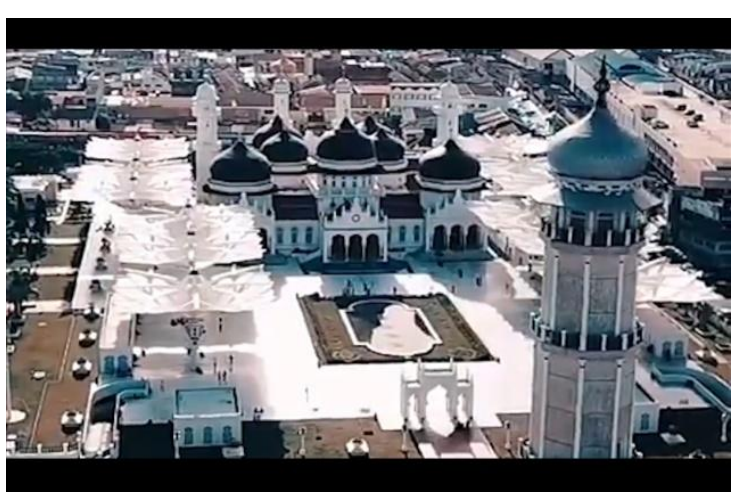

14.

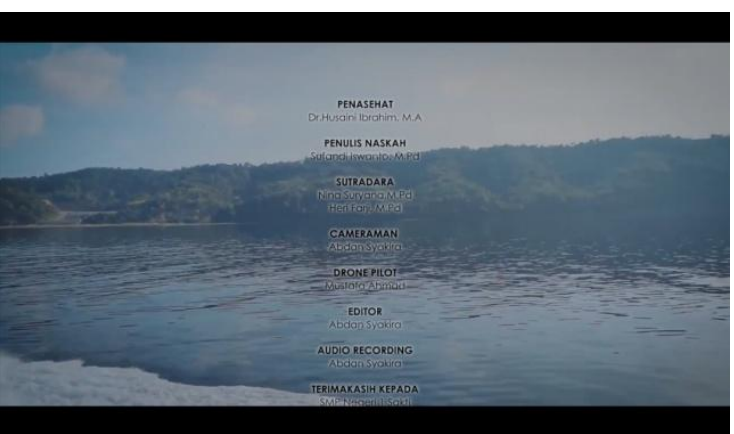

Gambaran Situs secara keseluruhan

Situs-situs tersebut hanya sebagian dari banyak situs lain yang ada di Aceh. Sebagai masyarakat Aceh sudah sepatutnya kita menjaga dan memelihara situs-situs tersebut. Menjaga dan memelihara merupakan cerminan dari kesadaran kita terhadap sejarah. Situssitus tersebut juga menjadi pijakan kita akan fakta dan realita bahwa tsunami pernah terjadi di Aceh. Dengan menjaga dan merawat situs-situs bersejarah, sama dengan kita mengenal diri sendiri dan sejarah bangsanya.

\section{Penutup}

Selajutnya prototype media yang

telah disusun sesuai dengan prosedur pengembangan media, kemudian dilakukan uji validasi oleh ahli materi dan ahli media. Pengujian validitas dilakukan oleh ahli yang memiliki keahlian dalam bidang kependidikan atau pembelajaran. Validasi dilakukan untuk mengetahui apakah media yang dikembangkan layak untuk di lanjutkan ke tahap uji efektivitas atau, diproduksi pada kelas yang lebih besar atau tidak.

Berdasarkan uji validitas oleh ahli materi, dari beberapa aspek mendapatkan nilai rata-rata 5 yang termasuk kategori sangat baik. Sedangkan dari ahli media dengan penilaian dari beberapa aspek, mendapatkan nilai rata-rata 5 yang juga masuk kategori sangat baik. Dengan demikian, dapat disimpulkan media pembelajaran IPS berbasis situs tsunami untuk meningkatkan kesadaran sejarah bisa dilanjutkan ke tahap selanjutnya. Dengan catatan adanya revisi materi yang harus dipersingkat dengan tujuan singkat, padat dan jelas. Pada bagian media bagian gambar dibuat lebih terang dan keterangan lebih diperjelas.

Lebih lanjut, uji coba terbatas sama dengan uji coba skala kecil dilakukan pada siswa SMP N 4 Sakti yang berjumlah 5 orang. Pemilihan 5 siswa tersebut dengan pertimbangan siswa memiliki tingkat prestasi yang berbeda. Hal ini dilakukan untuk mengetahui apakah semua siswa dapat memahami aspek media yang dikembangkan. Dari jumlah skor yang diberikan kelima siswa tersebut, diperoleh 
nilai rata-rata 4,5 dari total skor 87. pada beberapa bagian aspek. Adapun Berdasarkan hasil tersebut dapat perolehan skor dari kelima siswa pada uji disimpulkan media termasuk dalam coba terbatas dari skor 87 dapat kategori sangat baik. Dengan catatan revisi ditunjukkan pada gambar 1.

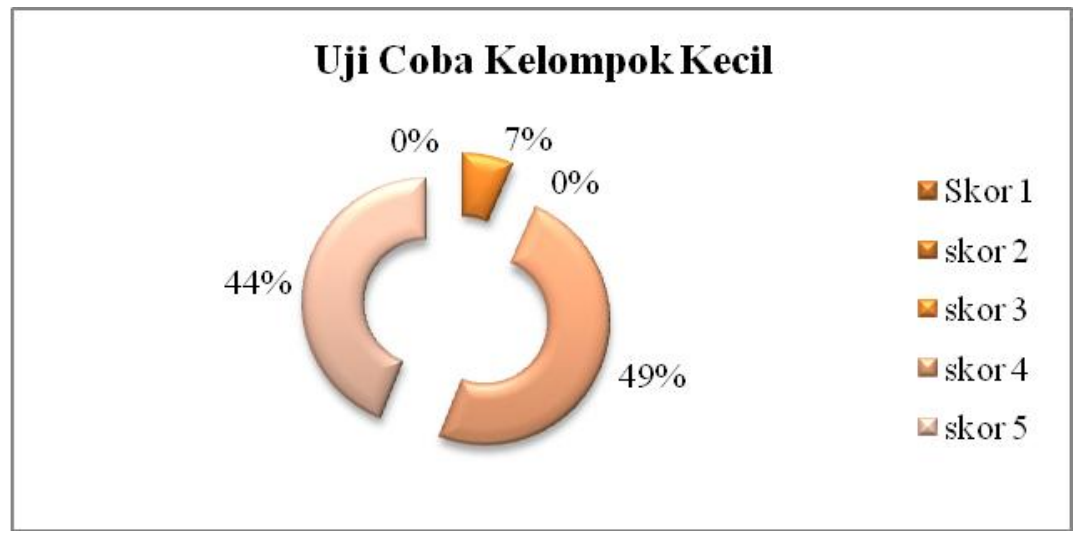

Gambar 1. Pie Persentase Uji Coba Skala Kecil

(data uji coba peneliti pada kelompok kecil, 2019)

Selanjutnya, uji coba kelompok baik, tanpa ada revisi. Dengan demikian besar atau uji coba skala luas juga media pembelajaran selanjutnya bisa di dilakukan pada siswa SMP Negeri 4 Sakti produksi atau bisa dilakukan uji efektifan dengan memilih 11 orang siswa. pada uji skala diperluas. Gambar 2 Pertimbangan dari kesebelas siswa menunjukkan perolehan skor dari tersebut dipilih dengan tingkat prestasi kesebelas siswa pada uji coba skala luas. yang berbeda-beda. Nilai rata-rata yang diberikan sebesar 4,6 dari total skor 229. Berdasarkan hasil dari nilai rata-rata tersebut dapat disimpulkan bahwa media pembelajaran IPS berbasis situs-situs tsunami termasuk dalam kategori sangat

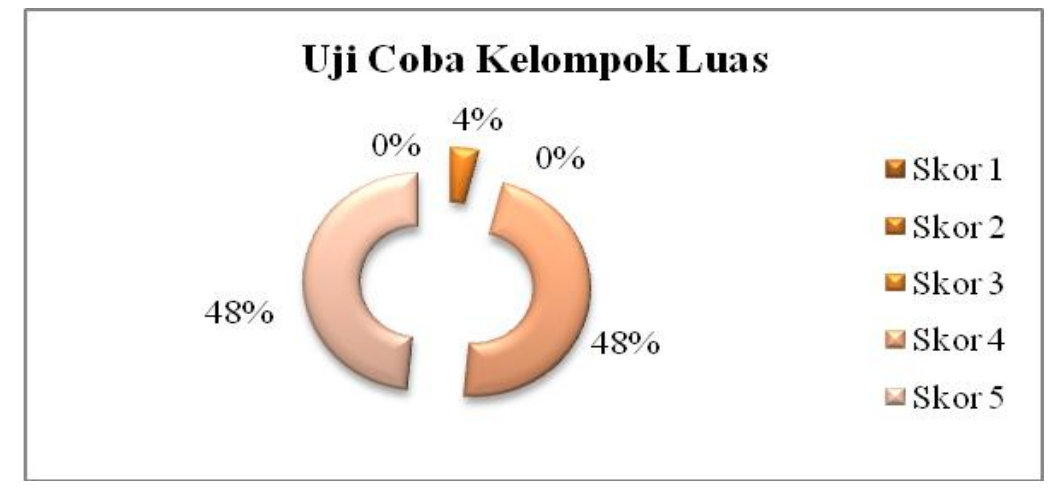

Gambar 2. Pie Persentase Uji Coba Skala Besar (Kelompok Besar) (data uji coba peneliti pada kelompok luas, 2019) 
Selanjutnya, tahap uji efektivitas media pembelajaran dilakukan pada dua sekolah, yaitu SMP Negeri 1 dan SMP Negeri 3 Sakti. Pemilihan kedua sekolah tersebut karena tahap ini digunakan metode eksperimen. Di mana SMP Negeri 1 Sakti sebagai kelompok eksperimen dan SMP Negeri 3 Sakti sebagai kelompok kontrol. Media yang dikembangkan menekankan pada sikap kesadaran sejarah siswa, maka penilaian yang dilakukan menggunakan kuesioner atau angket.

Angket disebarkan pada pre test dan post test baik pada kelas kontrol maupun kelas eksperimen. Pada kelompok kontrol materi situs-situs tsunami di terapkan dengan menggunakan media power point, sedangkan pada kelompok eksperimen menggunakan media audio visual berbasis situs-situs tsunami.

\section{Uji Kesetaraan Pre Test Kelompok Kontrol dan Eksperimen}

Uji ini merupakan uji kesetaraan dengan bentuk pre test angket tingkat kesadaran sejarah siswa pada kelompok kontrol dan kelompok eksperimen. Guna mengetahui tingkat kesadaran sejarah siswa. Adapun hasil uji coba pre test pada SMP Negeri 3 Sakti sebagai kelompok kontrol dan SMP Negeri 1 Sakti sebagai kelompok eksperimen seperti ditunjukkan pada tabel 2.

Tabel 2. Pre Test (Uji Kesetaraan) Tingkat Kesadaran Sejarah Siswa

\begin{tabular}{cccccc}
\hline & \multicolumn{3}{c}{ Kelompok Kontrol } & \multicolumn{3}{c}{ Kelompok Eksperimen } \\
\hline $\begin{array}{c}\text { Jumlah } \\
\text { Siswa }\end{array}$ & Skor Nilai (jumlah) & Nilai Rata-Rata & Jumlah Siswa & Skor Nilai & Nilai \\
25 & 3458 & 145 & 25 & (jumlah) & Rata-Rata \\
& & & & 3449 & 141 \\
\hline
\end{tabular}

Untuk hasil uji normalitas pre test Test. Adapun hasil uji coba tersebut dapat tingkat kesadaran sejarah siswa pada ditunjukkan pada tabel 3.

kedua kelompok dilakukan dengan menggunakan perhitungan SPSS, dengan rumus One Sample Kolmogorov Smirnov

Tabel 3. Pre Test (Uji Normalitas) Tingkat Kesadaran Sejarah Siswa

\begin{tabular}{|c|c|c|c|c|}
\hline Kelompok & Derajat Bebas & Kolmogorov Smirnov & Sig. (2-tailed) & Simpulan \\
\hline Kontrol & 25 & 1.218 & 0.104 & Normal \\
\hline Eksperimen & 25 & 0.808 & 0.975 & Normal \\
\hline
\end{tabular}

disimpulkan bahwa nilai signifikansinya adalah > 0.05. Dengan demikian uji normalitas pada kelompok kontrol dan eksperimen memiliki nilai distribusi normal. Nilai signifikannya (2-tailed) pada kelompok kontrol $0.104>0.05$ dan kedua kelompok berdistribusi normal. Selanjutnya dilakukan uji homogenitas sebagai syarat kedua dari uji-t. Perhitungan menggunakan program SPSS 20 dengan menggunakan Oneway Anova. Tabel 4 menunjukkan hasil uji homogenitas. 
Tabel 4. Pre Test (Uji Homogenitas) Tingkat Kesadaran Sejarah Siswa

\begin{tabular}{cccccc}
\hline & \multicolumn{2}{c}{ Test of Homogenety of Varian } & & \multicolumn{2}{c}{ Anova } \\
\hline Levene Statistic & df1 & df2 & Sig. & F & Sig. \\
0.674 & 1 & 56 & 0.387 & 8.808 & 0.005 \\
\hline
\end{tabular}

Data dikatakan homogen jika nilai dan uji homogenitas, yang mana masing-

signifikansinya adalah $>0.05$. Dari tabel 4 masing uji menunjukkan data normal dan diketahui bahwa hasil uji homogenitas homogen, maka selajutnya dilakukan uji-t. adalah $0.005>0.05$. Dengan demikian, Tabel 5 menunjukkan hasil uji-t dengan dapat disimpulkan bahwa skor pre test menggunakan perhitungan independent angket kesadaran sejarah siswa adalah sample test.

homogen. Setelah dilakukan uji normalitas

Tabel 5.Uji-t Pre Test Kelompok Kontrol dengan Kelompok Eksperimen

\begin{tabular}{lcccc}
\hline Pair 1 & $\mathbf{t}$ & $\mathbf{N}$ & df & Sig. (2-tailed) \\
Kontrol & -2.788 & 25 & 46 & 0.223 \\
Eksperimen & & & &
\end{tabular}

Berdasarkan tabel uji-t pre test

tersebut, dapat diketahui signifikansinya sebesar $0.223>0.05$. Sehingga hasil uji mendapatkan keputusan bahwa hipotesis $\mathrm{H}_{\mathrm{o}}$ ditolak. Sehingga disimpulkan bahwa siswa pada kelompok kontrol (SMP Negeri 3 Sakti) dengan kelompok eksperimen (SMP Negeri 1 Sakti) memiliki skor kesadaran sejarah yang sama. Dengan demikian berdasarkan uji sebelumnya, SMP Negeri 3 Sakti dan SMP Negeri 1 Sakti layak untuk dijadikan sebagai kelompok uji coba keefektifan media pembelajaran IPS berbasis situs-situs tsunami.
Uji Skor Post Test Kesadaran Sejarah Kelompok Kontrol dan Eksperimen

Salah satu upaya yang dilakukan untuk mengetahui keefektifan media pembelajaran, harus dilakukan kembali uji keefektifan. Uji dilakukan melalui uji nilai pos test antara kelompok kontrol dengan eksperimen. Nilai yang dibandingkan merupakan skor angket kesadaran sejarah siswa, yang mana kelompok kontrol hanya diberikan media power point. Sedangkan pada kelompok eksperimen diberikan media pembelajaran audio visual. Uji ini menggunakan uji dua sisi dengan tingkat signifikan $\alpha=0.05$. Tabel 6 menunjukkan hasil uji keefektifan media pembelajaran.

Tabel 6. Perolehan Skor Post Test Kesadaran Sejarah

\begin{tabular}{cccccc}
\hline & Kelompok Kontrol & & \multicolumn{3}{c}{ Kelompok Eksperimen } \\
\hline Jumlah Siswa & Skor Nilai (jumlah) & Nilai Rata- & Jumlah & Skor Nilai & Nilai \\
& & Rata & Siswa & (jumlah) & Rata-Rata \\
25 & 3755 & 149,5 & 25 & 3850 & 153 \\
\hline
\end{tabular}

Untuk uji normalitas dilakukan utama, adapun hasil uji normalitas dengan dengan menggunakan uji-t sebagai syarat menggunakan program SPSS 20. Pada 
program ini yang perlu diperhatikan adalah hasil dari One Sample Kolmogorov Smirnov
Test. Adapun hasil uji coba normalitas seperti ditunjukkan pada tabel 7.

Tabel 7. Uji Normalitas Skor Post Test Kesadaran Sejarah

\begin{tabular}{lcccc}
\hline \multicolumn{1}{c}{ Kelompok } & Derajat Bebas & Kolmogorov Smirnov & Sig. (2-tailed) & Simpulan \\
\hline Kontrol & 25 & 1.221 & 0.113 & Normal \\
Eksperimen & 25 & 0.924 & 0.992 & Normal \\
\hline
\end{tabular}

Berdasarkan hasil perhitungan sebab itu dapat ditarik kesimpulan bahwa

statistik uji normalitas pos test kesadaran skor dari kedua kelompok berdistribusi sejarah siswa dinyatakan signifikan, jika normal. Selanjutnya dilakukan uji taraf signifikansinya $>0.05$ baru dikatakan berdistibusi normal. Dari tabel diatas menunjukkan bahwa data berdistibusi normal. Oleh karena nilai signifikansi dari kelompok kontrol $0.113>0.05$ dan homogenitas yang merupakan syarat kedua dalam uji-t. Pada uji homogenitas juga menggunakan program SPSS 20 dengan menggunakan rumus Oneway Anova. Tabel kelompok eksperimen $0.992>0.05$. Oleh 8 menunjukkan hasil uji coba homogenitas.

Tabel 8.Uji Homegenitas Pos Test Kelompok Kontrol dengan Eksperimen

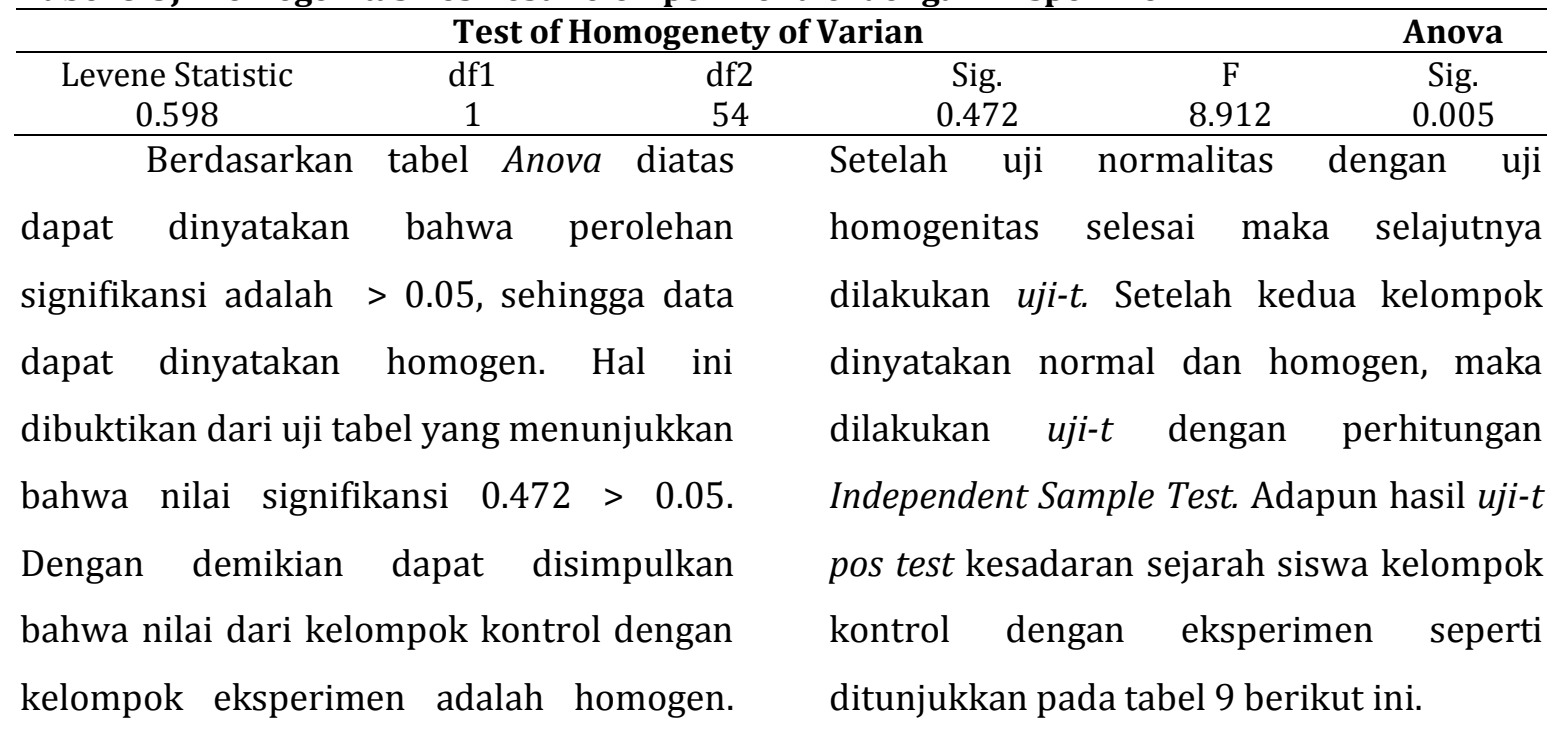

Tabel 9.Uji-t Pos Test Kelompok Kontrol dan Eksperimen

\begin{tabular}{lcccc}
\hline Pair 1 & $\mathbf{t}$ & $\mathbf{N}$ & df & Sig. (2-tailed) \\
Kontrol & -2.991 & 25 & 46 & 0.005 \\
\hline
\end{tabular}

Eksperimen

Oleh karena uji ini menggunakan uji

dua sisi, maka yang digunakan untuk taraf signifikansinya adalah Sig. (2-tailed). Dari tabel diatas dapat dilihat bahwa nilai perolehan Sig. (2-tailed) sebesar 0.005 $<0.025$, berdasarkan perhitungan $t_{h i t}(-$ $2.991)>t_{t a b}(-2.064)$ dengan menggunakan taraf signifikan 0.05. Dengan demikian dari hasil uji tersebut dapat disimpulkan bahwa $\mathrm{H}_{\mathrm{o}}$ ditolak. Sehingga hasil uji menyatakan bahwa terdapat perbedaan pengaruh yang positif dan signifikan dari skor kesadaran sejarah siswa antara kelompok kontrol 
(SMP Negeri 3 Sakti) dengan kelompok eksperimen (SMP Negeri 1 Sakti).

\section{Penutup}

\section{Kesimpulan}

Penggunaan media pembelajaran IPS pada SMP Negeri Se-Kecamatan Sakti selama ini masih jarang. Umumnya guru sudah menggunakan metode cooperative learning, dan hanya digunakan saat pembelajaran tertentu. Selebihnya menggunakan metode konvensional dengan media yang digunakan adalah microsof office powerpoint. Walaupun di SMP Negeri 4 Sakti sudah menggunakan media film dokumenter, gambar, peta konsep dan peta, namun belum pernah mengkombinasi dengan materi lokal. Fasilitas sekolah masih dianggap kurang memadai untuk menggunakan media pembelajaran. Sebab hanya terdapat satu unit LCD dan infokus.

Sekolah belum memiliki laboratorium khusus dan belum memiliki koneksi internet. Pengembangan media pembelajaran IPS berbasis situs tsunami diperlukan guna meningkatkan kesadaran sejarah siswa. Oleh karena dilatarbelakangi temuan penggunaan media pembelajaran masih jarang dan belum pernah memasukkan materi berbasis sejarah lokal. Selain itu, tingkat kesadaran sejarah siswa masih kurang. Sehingga disusun model prototype media pembelajaran IPS berbasis situs-situs Tsunami dengan tahapan Borg and Gall. Hasil uji keefektifan media pembelajaran IPS berbasis situs-situs tsunami dapat meningkatkan kesadaran sejarah siswa SMP Negeri Kecamatan Sakti. Dibuktikan dengan hasil data statistik yang menggunakan metode eksperimen dengan menggunakan uji-t. Dari hasil pre test antara kelompok kontrol dan eksperimen mendapatkan nilai rerata yang tidak jauh berbeda. Selain itu, nilai kesadaran sejarah kelompok eksperimen meningkat. Sehingga terjadi peningkatan kesadaran sejarah siswa yang menggunakan media pembelajaran IPS berbasis situs tsunami.

\section{Daftar Pustaka}

Agung, L., \& Wahyuni, S. (2013). Rencana Pembelajaran Sejarah. Yogyakarta: Ombak.

Ahmadi, \& Dkk. (2011). Strategi Pembelajaran Berorientasi KTSP. Jakarta: Prestasi Pustakaraya.

Ahmadi, F., \& Ibda, H. (2018). Media Literasi Sekolah (Teori dan Praktik) (Kedua; D. M. Wijayanti, Ed.). Semarang: CV. Pilar Nusantara

Ali, R. M. (2005). Pengantar Ilmu Sejarah Indonesia (Cetakan I; R. Widada, Ed.). Yogyakarta: PT LKiS Pelangi Aksara.

Aswasulasikin. (2018). Filsafat Pendidikan Operasional. Yogyakarta: Deepbulsh.

Bryant, E. (2007). Tsunami Bahaya yang Diabaikan. Bandung: Pakar Raya.

Ch, H. N. A. (2010). Matahari Pembaharuan (Cetakan I). Yogyakarta: Percetakan Galangpress.

Departemen Pendidikan dan Kebudayaan. (1993). Kamus Besar Bahasa Indonesia. Jakarta: Balai Pustaka.

Gall, M. D., Gall, J. P., \& Borg, W. R. (2003). Educational research: An introduction (7th ed.). In Boston, 
MA: A \& B Publications.

Hamid, A. R. (2014). Pembelajaran Sejarah (1st ed.). Yogyakarta: Ombak.

Irwansyah, T. (2012). Tsunami Aceh Hasil Rekayasa Teknologi. Yogyakarta: Tjap Kantjil.

Iswanto, S., Warto, \& Djono. (2015). Pengembangan Bahan Ajar Sejarah Lokal Berbasis Nilai-Nilai Sulam Kerawang Gayo untuk Meningkatkan Kesadaran Sejarah Siswa Kelas XI SMA Negeri Kabupaten Bener Meriah. Universitas Sebelas Maret.

Joebagio, H., \& Sariyatun. (2015). Model Media Pembelajaran IPS Berbasis Visualisasi Keunikan dan Local Wisdom Aneka Pemukiman Etnis untuk Edukasi Harmoni Sosial dan Strategi Menghindari Konflik Primordial. Surakarta.

Miarso, Y. (2004). Menyemai Benih Teknologi Pendidikan. Jakarta: Kencana.

Muchsin, M. A., \& Umar, M. (2017). Kehidupan Masyarakat Nelayan di Kabupaten Aceh Jaya Pasca Bencana Tsunami Tahun 2004-2017 (Cetakan Pe; A. Manan, Ed.). Banda Aceh: Naskah Aceh.

Musfiqon. (2012). Pengembangan Media Belajar dan Sumber. Jakarta: Prestasi Belajar.

Printina, B. I. (2017). Penggunaan Sumber Belajar Digital Exelsa Moodle dan Komik Toondo Dalam Meningkatkan Kreativitas Belajar Sejarah. Agastya: Jurnal Sejarah dan Pembelajarannya, 7(2), 57-67. http://doi.org/10.25273/ajsp.v7i2. 1489

Putra, N. (2013). Research \& Development: Penelitian Pengembangan Suatu Pengantar (1st ed.). Jakarta: PT RajaGrafindo Persada.

Rokhman, N., \& Dkk. (2006). Pengembangan Kurikulum Pengetahuan Sosial Terpadu secara
Tematik di Tingkat SLTP : Sebuah Pemikiran Awal. Istoria: Jurnal Pendidikan Dan Ilmu Sejarah, 1(2).

Siswoyo, D. (2014). Ilmu Pendidikan. Yogyakarta: UNY Press.

Somantri, N. (2001). Pengembangan Media Belajar dan Sumber. Bandung: Rosda Karya.

Sujarwa. (2011). Ilmu Sosial \& Budaya Dasar Manusia dan Fenomena Sosial Budaya. Yogyakarta: Pustaka Pelajar.

Surahman, E., \& Mukminan. (2017). Peran Guru IPS sebagai Pendidik dan Pengajar dalam Meningkatkan Sikap Sosial dan Tanggung Jawab Sosial Siswa SMP. Harmoni Sosial: Jurnal Pendidikan IPS, 4(1), 1-13.

Suryana, N. (2014). Hubungan Antara Pemahaman Situs-Situs Tsunami dan Minat Belajar Sejarah dengan Kesadaran Sejarah (Survey pada Mahasiswa Program Studi Pendidikan Sejarah FKIP Universitas Syiah Kuala, Banda Aceh). Universitas Sebelas Maret.

Tamburaka, R. E. (1999). Pengantar Ilmu Sejarah Teori Filsafat Sejarah dan Iptek. Jakarta: Rineka Cipta.

Tim Pengembang Ilmu Pendidikan FIP UPI. (2007). Ilmu dan Aplikasi Pendidikan. Bandung: PT. Imtima.

Trianto. (2011). Mendesain Model Pembelajaran Inovatif-Progresif: Konsep, Landasan, dan Implementasinya (4th ed.). Jakarta: Kencana Prenada Media Group.

Uno, H. B., \& Mohammad, N. (2013). Pembelajaran dengan Pendekatan Pembelajaran Aktif, Inovatif, Lingkungan, Kreatif, Efektif, Menarik. Jakarta: Bumi Aksara.

Wati, E. R. (2016). Ragam Media Pembelajaran. Yogyakarta: CV. Solusi Distribusi.

Widja. (1989). Sejarah Lokal dalam Perspektif suatu Pengajaran Sejarah. Jakarta: Departemen Pendidikan 
dan Kebudayaan.

Widodo, H. (2015). Potret Pendidikan di Indonesia dan Kesiapan dalam Menghadapi Masyarakat Ekonomi Asia (MEA). Cendekia, 13(2), 293307.

Wiriaatmadja, R. (2002). Pendidikan Sejarah di Indonesia: Perspektif Lokal, Nasional, dan Global (A. Suwirta, Ed.). Bandung: Historia Utama Press.

Yusuf, A. M. (2017). Metode Penelitian Kuantitatif, Kualitatif \& Penelitian Gabungan (4th ed.). Jakarta: Kencana. 